Archives of Agriculture and Environmental Science

\title{
Effect of integrated nutrient management on growth and productivity of Withania somnifera (L.) Dunal in Kymore Plateau and Satpura hills of Madhya Pradesh, India
}

\author{
Atul Kumar Shrivastava* (iD , V.B. Upadhyay, D.S. Gautam, S. Sarvade and R.K. Sahu
}

College of Agriculture, Balaghat, Jawaharlal Nehru Krishi Vishwa Vidyalaya, Jabalpur-482 004, (Madhya Pradesh), INDIA 'Corresponding author's E-mail: atuls_1975@rediffmail.com

\section{ARTICLE HISTORY}

Received: 03 April 2018

Revised received: 25 April 2018

Accepted: 05 May 2018

\section{Keywords}

\section{Crop productivity}

Integrated nutrient management

Plant attributes

Recommended dose

Withania somnifera (L.)

\section{ABSTRACT}

The field experiment was carried out at the Dusty Acres Farm, Jawaharlal Nehru Krishi Vishwa Vidyalaya (JNKVV), Jabalpur, Madhya Pradesh to study the effect of integrated nutrient management for growth and yield of Withania somnifera (L.) Dunal (Variety: Jawahar Ashwagandha134). Tallest plants $(49.35 \mathrm{~cm})$ were observed at harvest stage, whereas higher number of branches per plant (5.78) of W. somnifera was observed at 90 DAS with T11, respectively. The mean number of leaves per plant (125.40) and LAI (10.345) of W. somnifera was higher at 90 DAS with T11. Mean CGR was maximum (2.536 $\mathrm{g} \mathrm{m}^{-2}$ week $^{-1}$ ) and mean RGR was highest $\left(0.098 \mathrm{gg}^{-1} \mathrm{day}^{-1}\right)$ of W. somnifera at 90 DAS and thereafter decline at 120 DAS and harvest stage with T11. Whereas, mean dry matter $(1392.60 \mathrm{~kg} / \mathrm{ha})$ production of $W$. somnifera was higher at harvesting stage of crop with T11. Significantly higher mean root length $(16.30 \mathrm{~cm})$, root girth $(2.26 \mathrm{~cm})$ and mean dry root yield $(612.8 \mathrm{~kg} / \mathrm{ha})$ of $W$. somnifera was recorded under T11 than the rest of treatments. Mean number of berries per plant (30.78) and mean number of seeds per berry (194.17) of W. somnifera were significantly higher under T11. Higher mean seed yield (62.6 kg/ha) and harvest index (43.61\%) of W. somnifera was observed under T11 as compared to other treatments. Therefore, $100 \%$ recommended dose of NPK through fertilizers along with vermicompost ( $2.5 \mathrm{t} / \mathrm{ha}$ ), FYM (5.0 t/ha) and $\mathrm{ZnSO}_{4} 20 \mathrm{~kg} / \mathrm{ha}$ (T11) followed by $50 \%$ recommended dose of NPK through fertilizers along with vermicompost ( $2.5 \mathrm{t} / \mathrm{ha}$ ), FYM (5.0 t/ha) and $\mathrm{ZnSO}_{4} 20 \mathrm{~kg} / \mathrm{ha}$ (T14) and 100\% recommended dose of NPK through fertilizers along with vermicompost ( $2.5 \mathrm{t} / \mathrm{ha}$ ) and $\mathrm{ZnSO}_{4} 20 \mathrm{~kg} / \mathrm{ha}$ (T10) were found to be better integrated nutrient management for the cultivation of W. somnifera.

(C)2018 Agriculture and Environmental Science Academy

Citation of this article: Shrivastava, A.K., Upadhyay, V.B., Gautam, D.S., Sarvade, S. and Sahu, R.K. (2018). Effect of integrated nutrient management on growth and productivity of Withania somnifera (L.) Dunal in Kymore Plateau and Satpura hills of Madhya Pradesh, India. Archives of Agriculture and Environmental Science, 3(2): 202-208, https://dx.doi.org/10.26832/24566632.2018.0302015

\section{INTRODUCTION}

Withania somnifera (L.) is generally or locally named as ashwagandha, it is an important medicinal plant and generally used as a home remedy against numerous diseases in India as well as other parts of the world (Owasis et al., 2005). In Ayurveda, W. somnifera is widely claimed to have potent aphrodisiac, sedative, rejuvenative and life prolonging properties. It is mainly applied as energy boosting agent and known as Medharasayana, which means that which promotes 'learning and a good memory' and in geriatric problems (Williamson, 2002). The plant is traditionally used to promote youthful vigour, endurance, strength, and health, nurturing the time elements of the body and increasing the production of vital fluids, muscle fat, blood, lymph, semen and cells. It is seemed to be likely to the restorative characteristics of the roots of Ginseng to the roots of W. somnifera and named as Indian Ginseng (Singh and Kumar, 1998). It also helps counteract chronic fatigue, weakness, dehydration, bone weakness, loose teeth, thirst, impotency, premature ageing, emaciation, debility and muscle tension (Singh and Kumar, 1998; Williamson, 2002).

Among the several constraints, improper nutrient management 
is one of the factors responsible for the low productivity (Sarvade et al., 2014; Chopra et al., 2017). Chemical fertilizers though played an important role to meet out the nutritional demand of the crop but continuous use of chemical fertilizers is reported to have deleterious effects on soil heath due to their ill effects on physical, chemical and biological properties of soil (Sarkar et al., 1997; Adhikary, 2014; Kumar, 2016; Nayak et al., 2015). However, in the use of organic manures along with inorganic fertilizers not only improve physico-chemical and biological properties of soil but also provides all the nutrients in available form to crop plants, which enhance growth and yield of $W$. somnifera. The rate of application of organic and inorganic fertilizers may differ from type of soil and availability of irrigation facilities. Application of FYM at the rate of $12.5 \mathrm{tha}^{-1}+12.5 \mathrm{mg}$ $\mathrm{P}_{2} \mathrm{O}_{5} \mathrm{~kg}^{-1}$ soil was the best treatment combination for ashwagandha roots in terms of nutrients uptake (Goel and Duhan, 2014) reported at Hissar, Haryana. Higher doses of inorganic fertilizers may cause damages to the soil properties directly and impacts on crop productivity. Thus, there is an urgent need to formulate integrated nutrient management for increasing the production and productivity of $W$. somnifera. Therefore, the study deals with effect of integrated nutrient management on growth and productivity of Withania somnifera (L.) Dunal in Kymore Plateau and Satpura Hills of Madhya Pradesh, India.

\section{MATERIALS AND METHODS}

The field experiment was carried out at the Dusty Acres Farm, Jawaharlal Nehru Krishi Vishwa Vidyalaya (JNKVV), Jabalpur, Madhya Pradesh to study the effect of integrated nutrient management for growth and yield of Withania somnifera (L.) Dunal. This farm comes under "Kymore Plateau and Satpura Hills" agro climatic zone as per classification by National Agricultural Resaerch Project. It has a typical sub-tropical climate with hot dry summers and cool dry winters. Temperature ranges from $20 \mathrm{C}$ in December-January months to $460 \mathrm{C}$ in May-June months. Average annual rainfall of the locality is $1315 \mathrm{~mm}$, which mostly received between mid June to end of September with an occasional winter showers during December and January months. The soil of experimental field was sandy loam in texture with $7.5 \mathrm{pH}, 0.18 \mathrm{dS} / \mathrm{m}$ EC and having good drainage. Soil analysis revealed that available nitrogen was low (202.0 kg/ ha) whereas available Phosphorus ( $16.25 \mathrm{~kg} / \mathrm{ha})$ and potassium $(236.0 \mathrm{~kg} / \mathrm{ha})$ were in the medium range. The organic carbon in the soil was $0.30 \%$ and $\mathrm{Zn}$ was $0.52 \mathrm{mg} / \mathrm{kg}$.

Jawahar Ashwagandha-134 was sown at $30 \mathrm{~cm} \times 10 \mathrm{~cm}$ spacing using a seed rate of $10 \mathrm{~kg} / \mathrm{ha}$ by hand dibbling at depth of $5 \mathrm{~cm}$ after opening furrows in each plot on 16th August during 200809. The total experimental area was $41.0 \mathrm{~m} \times 31.2 \mathrm{~m}$ and $4.0 \mathrm{~m} \times$ $3.6 \mathrm{~m}$ net plot size. The total 14 nutrient management treatments were applied randomly and replicate thrice in randomized block design (RBD). The details of treatments as: T1 $-100 \%$ NPK* (40:20:20) - Control; T2 -50\% NPK (20:10:10); T3 -100\% NPK + 5.0 ton/ha FYM**; T4 -50\% NPK + 5.0 ton/ha FYM; T5 $100 \%$ NPK + 0.5 ton/ha NOC (Neem Oil Cake) ${ }^{* * *} ;$ T6 -50\% NPK
+ 0.5 ton/ha NOC; T7 -100\% NPK + 2.5 ton/ha vermi-compost; T8 -50\% NPK + 2.5 ton/ha vermi-compost; T9 -100\% NPK + 5.0 ton/ha FYM + $20 \mathrm{~kg} \mathrm{ZnSO}_{4} ; \mathrm{T} 10-100 \% \mathrm{NPK}+2.5$ ton/ha vermicompost $+20 \mathrm{~kg} \mathrm{ZnSO}_{4} ; \mathrm{T} 11-100 \% \mathrm{NPK}+5.0$ ton/ha FYM+2.5 ton/ha vermi-compost + $20 \mathrm{~kg} \mathrm{ZnSO}$; T12 - 50\% NPK + 5.0 ton/ ha FYM +20 kg ZnSO 4 ; T13 -50\% NPK + 2.5 ton/ha vermicompost + $20 \mathrm{~kg} \mathrm{ZnSO}$; T14 -50\% NPK + 5.0 ton/ha FYM+2.5 ton/ha vermi-compost $+20 \mathrm{~kg} \mathrm{ZnSO}$.

The harvesting of net plot was carried out on 2nd March during 2008-09 and following observations were worked out on net plot basis. Aboveground bio-metric observations (Plant height, number of branches, number of leaves, leaf area index (LAI meter), Crop Growth Rate, Relative Growth Rate and dry matter production) and belowground bio-metric observations (Root length, root girth and dry root yield) at different time intervals were worked out for each treatment. Number of berries per plant, number of seeds per berry, test weight, seed yield and Harvest Index ( $\mathrm{HI}$ ) were worked out for yield and yield attributing characters. The methodology given by Singh et al. (1975) is adopted for growth and productivity analysis. The pooled data were statistically analyzed through ANOVA technique (Fisher, 1967).

\section{RESULTS AND DISCUSSION}

\section{Aboveground bio-metric observations}

Significant difference in the mean plant height of $W$. somnifera was recorded at 30,60,90, 120 days after sowing (DAS) and harvest stage of crop (Figure 1) under different treatments. Mean plant height $(4.90 \mathrm{~cm})$ of $W$. somnifera was noted minimum at 30 DAS stage with T2 treatment, whereas at harvest stage the maximum mean plant height $(49.35 \mathrm{~cm})$ of $W$. somnifera was recorded with T11 treatment. This may be due to balanced nutrition on account of application of FYM and vermicompost along with inorganic fertilizers which helped in better cell division, cell expansion and enlargement, led to higher plant height of W. somnifera at different stages. Kurian et al. (2000) and Singh et al. (2004) observed increase in growth and plant height with the application of fertilizers in different crop plants. Panchabhai et al. (2005) found an increase in plant height and biomass of $W$. somnifera with $50 \mathrm{Kg} \mathrm{N} /$ ha and $25 \mathrm{~kg} \mathrm{P}_{2} \mathrm{O}_{5} / \mathrm{ha}$.

Mean number of branches per plant of $W$. somnifera was increased with time under progressive growth stages of the crop (Figure 2). The minimum mean number of branches (1.35) of W. somnifera were observed at initial stage i.e. 30 DAS at T2 treatment, whereas maximum (5.78) at 90 DAS with T11 treatment. The higher values pertaining to the branches are the resultant of better supply of all the major and micro nutrients. Particularly, availability of zinc on addition of organic manures to the soil in conjunction with chemical fertilizers which increased the availability in absolute amount during vegetative and reproductive phase. Thus, resulting in more auxin concentration in plant and nitrogen metabolism, increased more number of branches at different growth stages. Thakur et al. (2015) reported high number of branches of Oenothera biennis L. with the application of 
45t/ha FYM. Sundharaiya et al. (2003) found an increase in number of branches per plant of sweet basil with the application of $12.5 \mathrm{t} / \mathrm{ha} \mathrm{FYM}+20 \mathrm{~kg}$ wettable Sulphur $+27.25 \mathrm{~kg} \mathrm{~N} / \mathrm{ha}$ through urea.

The mean number of leaves (4.15) of W. somnifera were minimum at initial stage i.e. 30 DAS with T2 treatment, which increased to a maximum level (125.40) at 90 DAS with T11 treatment (Figure 3). The increased values pertaining to the number of leaves clearly indicated the benefits of adding organic manures to the soil in conjunction with chemical fertilizers which increased the availability of nutrients due to improvement in physical and biological properties of soil, which in turn resulted in formation of more number of leaves under aforesaid treatments (Murarkar et al. 1998).

There was a significant difference in the mean leaf area index (LAI) per plant of W. somnifera was recorded at all growth stages of crop (Figure 4) under different treatments. The mean LAI increased with time under all the growth stages of the crop. The mean LAI was minimum (0.342) at initial stage i.e. 30 DAS with T2 treatment but reached to the maximum level (10.345) at 90 DAS with T11 treatment. This may have ultimately increased the assimilatory area to that of other treatments, whereas reverse was true for rest of the treatments. These findings are in closely uniformity to that of Shashidhara and Shivmurthy (2008).

There was a significant difference in the mean crop growth rate (CGR) and mean relative growth rate (RGR) of $W$. somnifera recorded at all growth stages under different nutrient management (Figures 5 and 6). Mean CGR (2.536 $\mathrm{g} \mathrm{m}^{-2}$ week $^{-1}$ ) of W. somnifera was recorded maximum at 90 DAS with T11 treatment. Whereas, mean RGR (0.024 $\left.\mathrm{gg}^{-1} \mathrm{day}^{-1}\right)$ was observed minimum at initial stage i.e. 30 DAS with T2 treatment, while it was highest $(0.098$ $\mathrm{gg}^{-1} \mathrm{day}^{-1}$ ) at 90 DAS and there was decline in RGR at 120 DAS and harvest stage with T11 treatment. The application of $100 \%$ recommended dose of NPK fertilizers along with $2.5 \mathrm{t} / \mathrm{h}$ a vermicompost and 5.0 t/ha FYM as well as $20 \mathrm{~kg} / \mathrm{ha} \mathrm{ZnSO}_{4}$ lead to enhance the availability of all essential to the crop plants. Vermicompost and FYM contain living cells of different types of micro-organism, which have ability to make the soil more biologically active as well as upgrade the soil fertility and productivity through nitrogen fixation, breakdown of organic materials and nutrient release, solubilisation of insoluble phosphorus and improvement in soil structure due to better soil aggregation. Thus, the integrated supply of organic manures, inorganic fertilizers along with micronutrients resulted in balanced and timely supply of nutrients as per the need of crop, which ultimately increased both the growth parameters as well as dry matter production of crop. These findings are corroborating with findings of Ajay et al. (2005); Singh and Agrawal (2001).

The mean dry matter production was minimum (181.67 kg/ha) at initial stage (30 DAS) with T2 treatment and attained the maximum value $(1392.60 \mathrm{~kg} / \mathrm{ha})$ at harvesting stage of crop with T11 treatment (Figure 7). This must have increased the photosynthesis during growth stages of plant leading accumulation of carbohydrates, proteins and fats, resulting in gradual increase of dry matter production. Preetha et al. (2005) found an increase dry matter production (9.62 g/plant) of amarnath with $5 \mathrm{t} / \mathrm{ha}$ vermicompost and $50 \mathrm{~kg} / \mathrm{ha} \mathrm{N}, 50 \mathrm{~kg} / \mathrm{ha} \mathrm{P}_{2} \mathrm{O}_{5}$ and 50 $\mathrm{kg} / \mathrm{ha} \mathrm{K}_{2} \mathrm{O}$ over $(0.98 \mathrm{~g} /$ plant) control. Similarly results were reported by Rao et al. (2004).

\section{Belowground bio-metric observations}

Root of W. somnifera is one of the most important parts of commercial values. Thus better root growth and yield ensures higher economical returns to the farmers. The mean root length varied from $11.7 \mathrm{~cm}$ to $16.3 \mathrm{~cm}$ in plots receiving different integrated nutrient management (Table 1). The mean root length under T11 was significantly higher than rest of the treatments. The mean root girth $(\mathrm{cm})$ in case of treatment T11 (2.26) was significantly higher and proved superior over rest of the treatments (Table 1). It was followed by T14 (2.06), T10 (1.95), T13 (1.90), T7 (1.79), T8 (1.75), T5 (1.73), T6 (1.71), T9 (1.70), T12 (1.68), T3 (1.64), T4 (1.62), T1 (1.55) and T2 (1.51) cm. The mean dry root yield in treatment T11 $(612.8 \mathrm{~kg} / \mathrm{ha})$ was significantly maximum, followed by T14 (555.8 kg/ha), T10 (513.4 kg/ha), T13 (487.3 kg/ha), T7 (448.9 kg/ha), T8 (429.4 kg/ha), T5 (422.1 kg/ ha), T6 (400.2 kg/ha), T9 (349.8 kg/ha), T12 (341.6 kg/ha), T3 (332.8 kg/ha), T4 (320.2 kg/ha), T1 (309.8 kg/ha) and T2 treatment (282.3 kg/ha) (Table 2). Akande (2006) also found $50.40 \%$ increase in root length over the control in Amaranthus and $64.6 \%$ increased in the root length of tap root of Aloe vera due to integrated supply of plant nutrients over control (Hasanuzzaman et al., 2008). Similarly, vermicompost 5t/ha and half RDF increased the root length (28.2\%), root girth (8.27\%) and root yield (65.3\%) of carrot over control (Sunandarani and Mallareddy, 2007).

The mean number of berries per plant of $W$. somnifera varied from 16.98 to 30.78 under different nutrient treatments (Table 1). The mean number of berries per plant of W. somnifera under T11 was significantly higher over all the treatments. However, T14 (29.29) was found to be statistically at par with T11 (30.78). The mean number of seeds per berry of $W$. somnifera was ranged between 132.50 to 194.17 under different treatments (Table 1). The mean number of seeds per berry of $W$. somnifera were higher under T11 (194.17) significantly and proved superior over T13 (177.50), T9 (169.17), T12 (161.00), T7 (152.50), T8 (149.17), T5 (148.50), T6 (147.50), T3 (142.83), T4 (141.67), T1 (140.00) and T2 (132.50) treatments but was at par with T14 (188.67) and T10 (184.17). It may be due to excellent growth and development of root and shoot particularly more assimilatory area (leaf area) on account of balanced and timely supply of all the essential nutrients which in turn led to better partitioning of photosynthate from source to the sink (seeds) under the aforesaid treatments in comparison to other treatments where imbalanced nutrients could not support the growth and development of roots, shoots and value of yield attributing traits. Those findings are in accordance with views of several research workers (Akanbi et al., 2007; Ullah et al., 2008; Thakur et al., 2015).

Crop yield

Mean seed yield $(62.6 \mathrm{~kg} / \mathrm{ha})$ of $W$. somnifera under T11 was 
recorded to be significantly superior over all the treatments but was statistically at par with T14 (59.2 kg/ha), T10 (57.2 kg/ha), T13 (56.1 kg/ha) and T7 (54.5 kg/ha) (Table 2). There was no significant difference in the mean test weight (1000 seed weight) of W. somnifera at different nutrient management treatments. However, treatment T11, T12 and T14 recorded higher $(1.85 \mathrm{~g})$ test weight. The mean harvest index ranged between 36.2 to $43.61 \%$ under different nutrient management treatments (Table 2). The mean harvest index (43.61\%) of W. somnifera with the treatment T11 was significantly superior over all the treatments but was at par to T14 (52.24\%). Seeds of W. somnifera are also important from farmer's point of view because they are used for sowing in the succeeding year. There was iden- tical increase the seed yield (41.9 per cent) of W. somnifera in plots receiving T11 treatment (100\% NPK and 2.5t/ha vermicompost as well as $5 \mathrm{t} / \mathrm{ha}$ FYM with $20 \mathrm{~kg} \mathrm{ZnSO}_{4}$ ) followed by $\mathrm{T} 14, \mathrm{~T} 10$ and T13 as compared to other treatments including T2 and T1 treatments. The higher seed yield under these treatments could be attributed to better growth and development of foliage of W. somnifera which intercepted and efficiently utilized the incident in higher meristematic activity, thus enhancing the growth and finally attained the higher seed yield on account of better and balanced portioning of photosynthates to the sink (seeds) from source (foliage). These findings are in closely conformity with the results of Thakur et al. (2015), Joon and Singh (1989) and Zende et al. (1998) for different medicinal crop plants.

Table 1. Mean root growth, yield attributes and yield at harvest of W. somnifera as influenced by different nutrient management.

\begin{tabular}{lcccc}
\hline \multirow{2}{*}{ Treatment } & \multicolumn{2}{c}{ Root growth } & \multicolumn{2}{c}{ Yield attributes } \\
\cline { 2 - 5 } & Length $(\mathbf{c m})$ & Girth $(\mathbf{c m})$ & Berries/plant & Seeds/berry \\
\hline $\mathrm{T}_{1}$ & 12.2 & 1.55 & 17.97 & 140.00 \\
$\mathrm{~T}_{2}$ & 11.7 & 1.51 & 16.98 & 132.50 \\
$\mathrm{~T}_{3}$ & 13.0 & 1.64 & 20.99 & 142.83 \\
$\mathrm{~T}_{4}$ & 12.8 & 1.62 & 18.57 & 141.67 \\
$\mathrm{~T}_{5}$ & 14.0 & 1.73 & 25.65 & 148.50 \\
$\mathrm{~T}_{6}$ & 13.8 & 1.71 & 24.48 & 147.50 \\
$\mathrm{~T}_{7}$ & 14.4 & 1.79 & 26.35 & 152.50 \\
$\mathrm{~T}_{8}$ & 14.2 & 1.75 & 25.93 & 149.17 \\
$\mathrm{~T}_{9}$ & 13.5 & 1.70 & 23.05 & 169.17 \\
$\mathrm{~T}_{10}$ & 14.7 & 1.95 & 27.92 & 184.17 \\
$\mathrm{~T}_{11}$ & 16.3 & 2.26 & 30.78 & 174.17 \\
$\mathrm{~T}_{12}$ & 13.2 & 1.68 & 21.60 & 161.00 \\
$\mathrm{~T}_{13}$ & 14.5 & 1.90 & 26.78 & 177.50 \\
$\mathrm{~T}_{14}$ & 15.4 & 2.06 & 29.29 & 188.67 \\
$\mathrm{SEm}_{\mathrm{n}}$ & 0.290 & 0.023 & 0.46 & 3.66 \\
$\mathrm{CD}$ at $5 \%$ & 0.842 & 0.066 & 1.33 & 10.63 \\
\hline
\end{tabular}

Table 2. Yield, test weight and harvest index of W. somnifera as influenced by different nutrient management.

\begin{tabular}{|c|c|c|c|c|}
\hline \multirow{2}{*}{ Treatments } & \multicolumn{2}{|c|}{ Yield (kg/ha) } & \multirow{2}{*}{ Test weight (g per 1000 seed) } & \multirow{2}{*}{$\begin{array}{c}\text { Harvest Index } \\
\text { (\%) }\end{array}$} \\
\hline & Dry Root & Seed & & \\
\hline $\mathrm{T}_{1}$ & 309.8 & 44.1 & 1.81 & 29.24 \\
\hline $\mathrm{T}_{2}$ & 282.3 & 36.2 & 1.81 & 27.84 \\
\hline $\mathrm{T}_{3}$ & 332.8 & 45.8 & 1.82 & 31.64 \\
\hline $\mathrm{T}_{4}$ & 320.2 & 44.4 & 1.81 & 28.61 \\
\hline $\mathrm{T}_{5}$ & 422.1 & 51.1 & 1.82 & 35.09 \\
\hline $\mathrm{T}_{6}$ & 400.2 & 50.7 & 1.81 & 33.85 \\
\hline $\mathrm{T}_{7}$ & 448.9 & 54.5 & 1.83 & 36.42 \\
\hline $\mathrm{T}_{8}$ & 429.4 & 53.4 & 1.82 & 35.54 \\
\hline $\mathrm{T}_{9}$ & 349.8 & 49.7 & 1.82 & 29.79 \\
\hline $\mathrm{T}_{10}$ & 513.4 & 57.2 & 1.83 & 40.49 \\
\hline $\mathrm{T}_{11}$ & 612.8 & 62.6 & 1.84 & 43.61 \\
\hline $\mathrm{T}_{12}$ & 341.6 & 48.2 & 1.82 & 28.60 \\
\hline $\mathrm{T}_{13}$ & 487.3 & 56.1 & 1.83 & 39.08 \\
\hline $\mathrm{T}_{14}$ & 555.8 & 59.2 & 1.83 & 42.24 \\
\hline SEm \pm & 5.45 & 2.64 & 0.016 & 0.42 \\
\hline CD at $5 \%$ & 15.83 & 7.68 & 0.048 & 1.22 \\
\hline
\end{tabular}




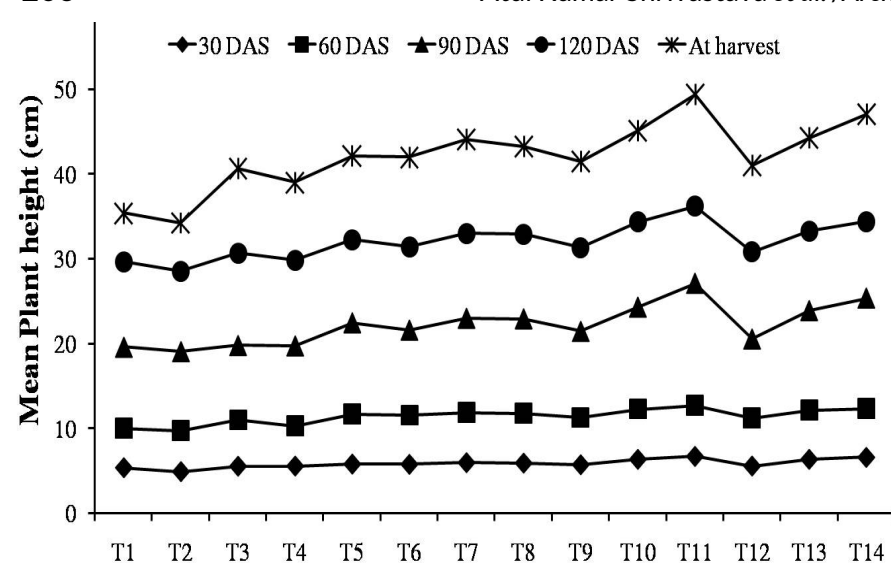

Figure 1. Mean plant height of W. somnifera at progressive stages of crop as influenced by different treatments.

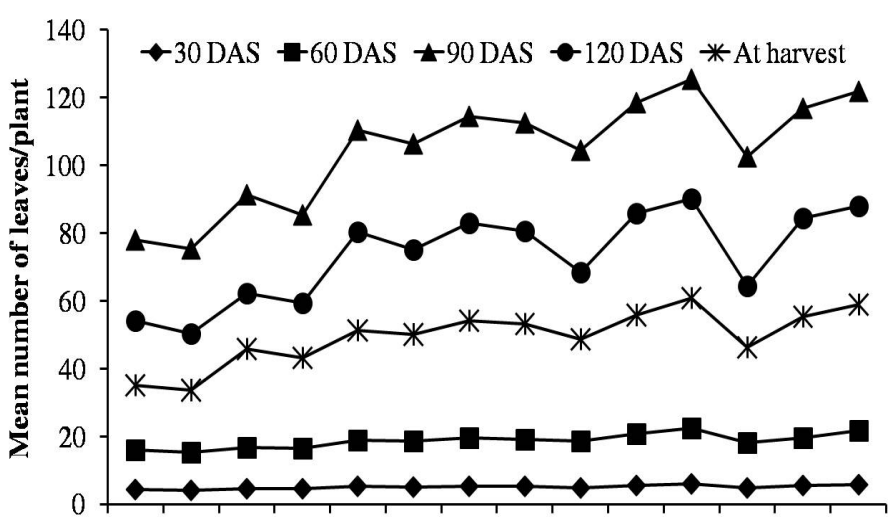

$\begin{array}{llllllllllllll}\mathrm{T} 1 & \mathrm{~T} 2 & \mathrm{~T} 3 & \mathrm{~T} 4 & \mathrm{~T} 5 & \mathrm{~T} 6 & \mathrm{~T} 7 & \mathrm{~T} 8 & \mathrm{~T} 9 & \mathrm{~T} 10 & \mathrm{~T} 11 & \mathrm{~T} 12 & \mathrm{~T} 13 & \mathrm{~T} 14\end{array}$

Figure 3. Mean number of leaves of $W$. somnifera at progressive stages of crop growth as influenced by different nutrient management.

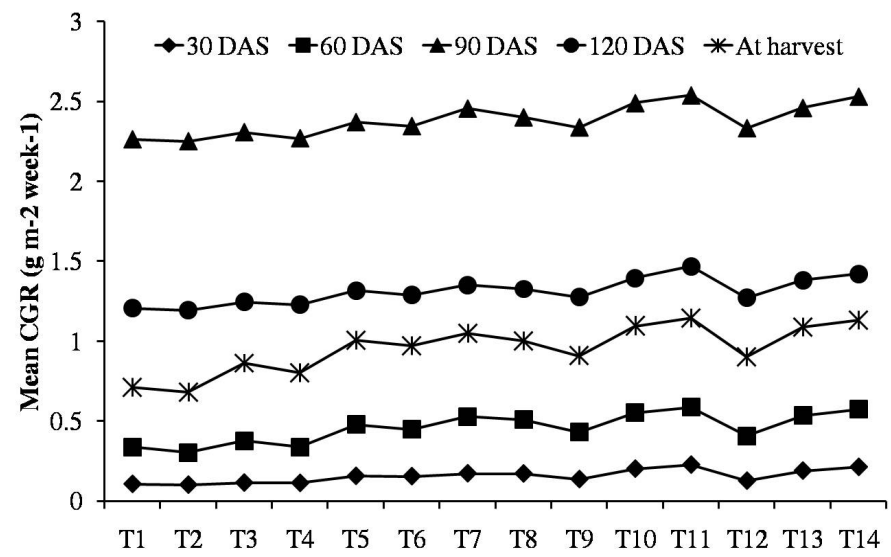

Figure 5. Mean crop growth rate (CGR) of W. somnifera at progressive stages of crop influenced by different nutrient management.

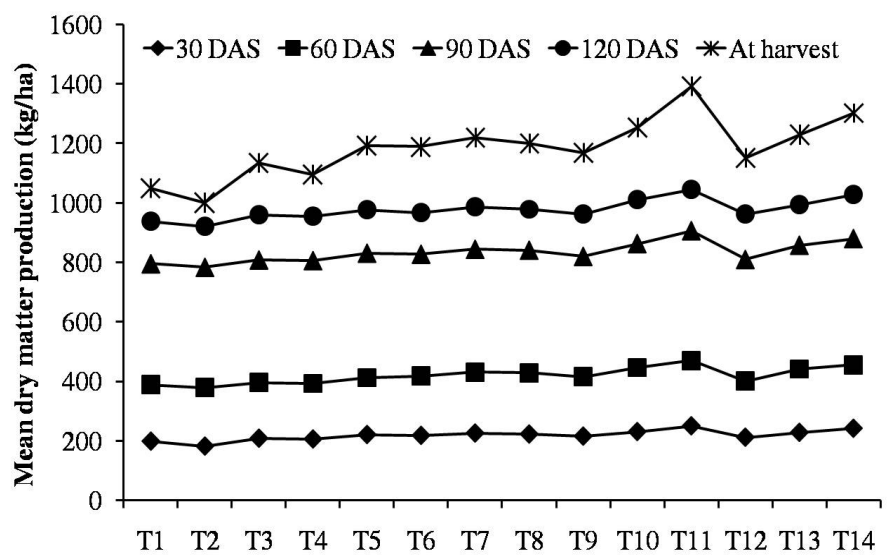

Figure 7. Mean dry matter production of W. somnifera at progressive stages of crop growth as influenced by different treatments.

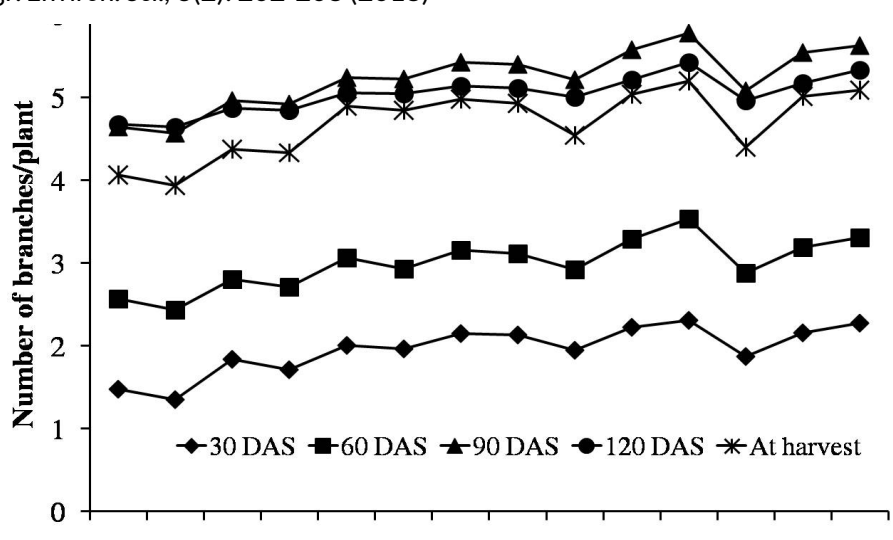

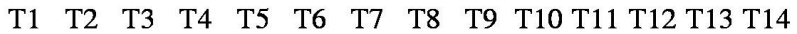

Figure 2. Mean number of branches of $\mathrm{W}$. somnifera at progressive stages of crop growth as influenced by different treatments.

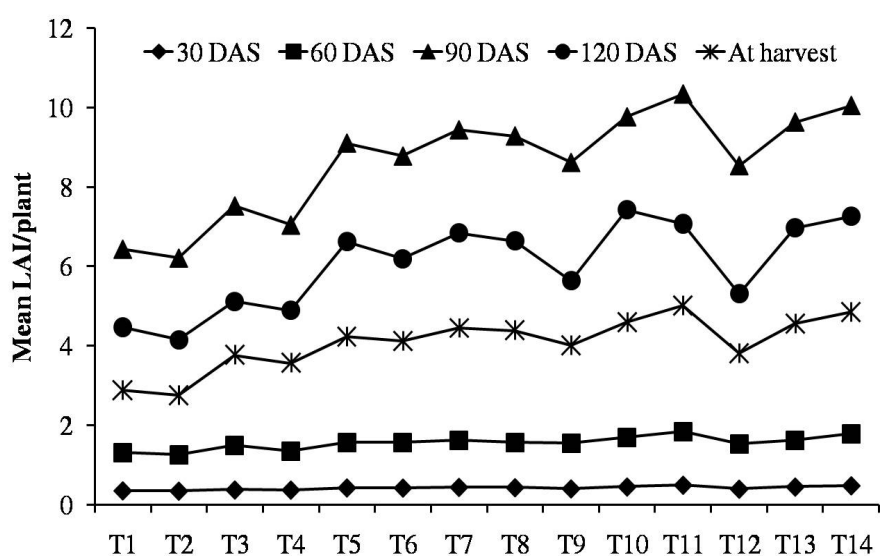

Figure 4. Mean leaf area index (LAI) of W. somnifera at progressive stages of crop growth as influenced by different nutrient management.

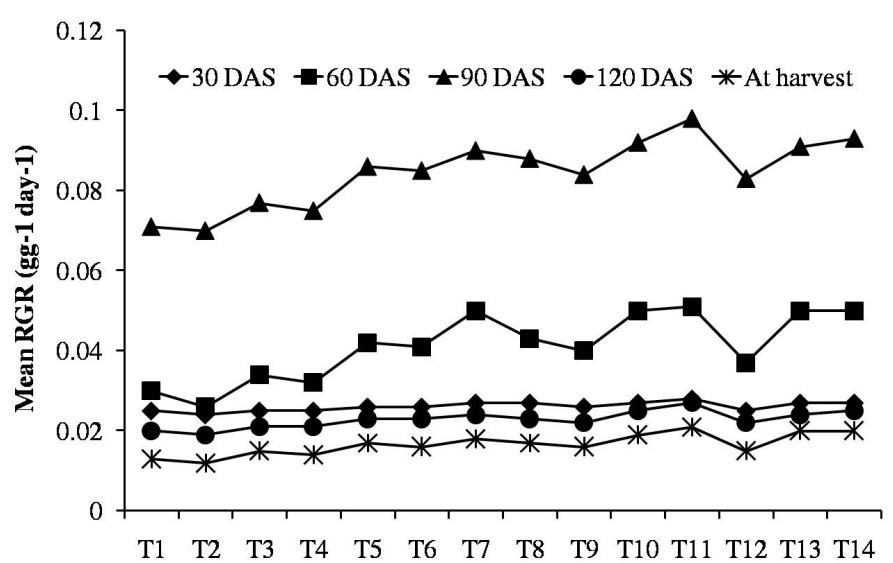

Figure 6. Mean relative growth rate (RGR) of W. somnifera at progressive stages of crop growth as influenced by different nutrient management.

Conclusion

It is concluded that the use of integrated nutrients was found effective for the cultivation of W. somnifera. The results of this investigation indicated that $100 \%$ recommended dose of NPK through fertilizers along with vermicompost (2.5 t/ha), FYM (5.0 $\mathrm{t} / \mathrm{ha}$ ) and $\mathrm{ZnSO}_{4} 20 \mathrm{~kg} / \mathrm{ha}$ (T11) followed by $50 \%$ recommended dose of NPK through fertilizers along with vermicompost ( $2.5 \mathrm{t}$ / ha), FYM (5.0 t/ha) and $\mathrm{ZnSO}_{4} 20 \mathrm{~kg} / \mathrm{ha}$ (T14) and 100\% recommended dose of NPK through fertilizers along with vermicompost (2.5 t/ha) and $\mathrm{ZnSO}_{4} 20 \mathrm{~kg} / \mathrm{ha}$ (T10) were found to be better integrated nutrient management for the cultivation of $W$. somnifera as these attained the superior values of aboveground 
bio-metric observations (Plant height, number of branches, number of leaves, leaf area index, crop growth rate, relative growth rate and dry matter production), belowground biometric observations (Root length, root girth and dry root yield) and yield (Mean seed yield, test weight and mean harvest index) of W. somnifera as compared to other integrated nutrient management treatments. Thus, application of integrated nutrient can be used to enhance the productivity of W. somnifera.

\section{ACKNOWLEDGEMENT}

The Authors are deeply indebted for financial support of Head Department of Plant Physiology, JNKVV, Jabalpur. Besides, this research work would not have been completed without the support of field assistants.

Open Access: This is open access article distributed under the terms of the Creative Commons Attribution License, which permits unrestricted use, distribution, and reproduction in any medium, provided the original author(s) and the source are credited.

\section{REFERENCES}

Adhikary, S.P. (2014). Studies on the influence of sugarcane trash vermi-compost on the growth and biochemical parameters of brinjal plant (Solanum melongena L.). The Ecoscan, 8(3\&4): 207-210, http://theecoscan.in/Journal PDF/ 83\&404\%20S\%20P 20ADHIKARY_3054_Ecos.pdf

Ajay, P., Ramesh, K., Reddy, S., Ramana, S. and Maji, B. (2005). Effect of nitrogen and farm yard manure of physiological parameters in ashwagandha under vertisol soil type. Indian Journal Plant Physiology, 10 (4): 389-393.

Akanbi, W.B., Adebooye, C.O., Togun, A.O., Ogunrinde, J.O. and Adeyeye, S.A. (2007). Growth, herbage and seed yield and quality of Telfairia occindentalis as influenced by cassava peet compost and mineral fertilizers. World Journal of Agricultural Sciences, 3 (4): 508-516;

Akande, M.O. (2006). Effect of organic root plus (biostimulant) on the growth, nutrient content and yield of Amaranthus. African Journal of Biotechnology, 5 (10): 871-874. https:// www.ajol.info/index.php/ajb/article/view/42909

Chopra, A.K., Temin, P., Srivastava, S. and Kumar, V. (2017). Effects of integrated nutrient management on agronomical attributes of tomato (Lycopersicon esculentum L.) under field conditions. Archives of Agriculture and Environmental Science, 2(2): 86-91.

Fisher, R.A. (1967). Statistical Methods for Research Workers. 13th Ed. Hafner Publishing. Edinburgh.

Goel, V. and Duhan B.S. (2014). Ashwagandha (Withania somnifera L. Dunal) crop as affected by the application of farm yard manure (FYM) and inorganic phosphorus in typic Torripsamment of Hisar. African Journal of Biotechnology, 13 (6): 743-748.

Hasanuzzaman, M., Ahmed, K.U., Khalequzzaman, K.M.,
Shamsuzzaman, A.M.M. and Nahar, K. (2008). Plant characteristics, growth and leaf yield of Aloe vera as affected by organic manure in pot culture. Australian Journal of Crop Science, 2(3): 158-163, http://www.cropj.com/Microsoft\% 20Word.

Joon, R.K. and Singh, K.P. (1989). Response of forage oat (Avena sativa L.) to irrigation and nitrogen. Forage Research, 14 (1): 29-37.

Kumar, V. (2016). Use of integrated nutrient management to enhance soil fertility and crop yield of hybrid cultivar of brinjal (Solanum melongena L.) under field conditions. Advances in Plants \& Agriculture Research, 4(2): 00130, https://dx.doi.org/10.15406/apar.2016.04.00130

Kurian, A., Sankar, A., Joseph, L., Keshavachandran, R., Nybe, E.V. and Nair, G.S. (2000). Two decades of research on medicinal plants at College of Horticulture, Kerala Agricultural University, Vellanikkara - An overview. Indian Journal of Arecanut, Spices and Medicinal Plants, 2(4): 115-139.

Murarkar, S.R., Tayade, A.S., Bodhade, S.N. and Ulemale, R.B. (1998). Effect of vermicompost on mulberry leaf yield. Journal of Soil and Crops, 8 (1): 85-87.

Nayak, T., Patel, T. and Bajpai, R. K. (2015). Influence of organic and inorganic fertilization on soil physical properties in a Vertisol under rice. The Ecoscan, 9(1\&2): 71-74.

Owasis, M., Sharad, K.S. Shehbaz, A. and Saleemuddin, M. (2005). Antibacterial efficacy of W. somnifera (ashwagandha) an indigenous medicinal plant against experimental murine salmonellosis. Phytomedicine, 12: 229235.

Panchabhai, D.M., Bachkar, B.R. Ghawade, S.M. and Wankhade, S.G. (2005). Effect of nitrogen and phosphorus on growth and seed yield of ashwagandha. Orissa Journal of Horticulture, 33 (1): 11-15.

Preetha, D., Sushma, P.K. and Marykutty, K.C. (2005). Vermicompost + inorganic fertilizers on promote yield and nutrient uptake of amaranth (Amaranthus tricolor L.). Journal of Tropical Agriculture, 43(1-2): 87-89.

Rao, U.V., Reddy, Y.R., Radha, C.K. and Reddy, C.R. (2004). Effect of organic and inorganic sources of nitrogen on growth, yield, nutrient uptake and economics of low land rice. Madras Agriculture Journal, 91(7-12): 389-393.

Sarkar, R.K., Karmakar, S. and Chakraborty, A. (1997). Response of summer green gram (Phaseolus radiatus) to nitrogen, phosphorus application and bacterial inoculation. Indian Journal of Agronomy, 38: 578-581.

Sarvade, S., Mishra, H. S., Kaushal, R., Chaturvedi, S., Tewari, S. and Jadhav, T. A. (2014). Performance of wheat (Triticum aestivum L.) crop under different spacings of trees and fertility levels. African Journal of Agricultural Research, 9(9): 866-873, http://www.academicjournals.org/app/webroot/ article/article1393579496_Sarvade\%20et\%20al.pdf

Shashidhara, G.B. and Shivmurthy, D. (2008). Studies on the effect of integrated nutrient management on growth, yield and yiled parameters of chilli genotypes under vertisol of north transition zone of Karnataka. Karnataka Journal of 
Agriculture Science, 21(3): 433-435.

Singh, J.S., Lauenroth, W.K. and Steinhorst, R.K. (1975). Review and assessment of various techniques for estimating net aerial primary production in grassland from harvest data. Botany Review, 41: 181-232.

Singh, K., Singh, P., Bey, S., Kumar, D. and Patra, D. (2004). Effect of NPK fertilizers on growth, oil, yield and quality of french basil (Ocimum basilicum L.). Journal of Spike and Agreomatic Crops, 13 (1): 52-54.

Singh, R. and Agarwal, S.K. (2001). Analysis of growth and productivity of wheat (Triticum aestivum L.) in relation to levels of FYM and nitrogen. Indian Journal of Plant Physiology, 6 (3): 279-283.

Singh, S. and Kumar, S. (1998). Withania somnifera: the Indian ginseng ashwagandha, Central Institute of Medicinal and Aromatic Plants, Lucknow, India.

Sunandrani, N. and Malareaddy, K. (2007). Effect of different organic manures and inorganic fertilizers on growth, yield and quality of carrot (Daucus carota L.). Karnataka Journal of Agriculture Science, 20 (3): 686-688.

Sundharaiya, K., Punnuswamay, V. and Velmurugan, S. (2003). Effect of FYM, sulphure and different nitrogen sources on herbage and seed yield of sweet basil. South Indian Horticulutre, 51 (1/6): 93-95.

Thakur, U., Dutt, B., Sarvade, S. and Sharma, K.R. (2015). Effect of FYM doses and plant spacing on production of Oenothera biennis L. Indian Journal of Ecology, 42(2): 359-362.

Ullah, M.S., Islam, M.S., Islam, M.A. and Haque, T. (2008). Effects of organic manures and chemical fertilizers on the yield of brinjal and soil properties. Journal of Bangladesh Agricultural University, 6(2): 271-276.

Williamson, E.M. (2002). Major Herbs of Ayurveda; Churchill Livingstone: London, UK, pp. 322-323.

Zende, G.K., Ruikar, S.K. and Joshi, S.N. (1998). Effect of application of vermicompost along with chemical fertilizers on sugarcane yield and juice quality. Indian Sugar, 48 (5): 357-369. 